\title{
Parameters of selective martite ores disintegration in structured ore bodies deposits by borehole hydraulic monitors
}

\author{
Mykola Stupnik $^{1 *}$, Viktor Tarasiutin ${ }^{1}$, and Pavlo Fedorenko ${ }^{1}$ \\ ${ }^{1}$ Kryvyi Rih National University, Department of Underground Mining of Mineral Deposit, \\ 11 Matusevycha Ave., 50027 Kryvyi Rih, Ukraine
}

\begin{abstract}
The work is aimed at determining parameters of advance borehole stoping by hydraulic monitors leading to rational use of reserves structured according to ore types at deposits by means of advance stoping with selective disintegration of high-grade martite ores. The research methods include experimental investigations of parameters of breaking a high-grade martite ore massif by high-pressure water jets of borehole monitors; laboratory studies of technological properties of hydrodisintegrated products and their concentratibility; theoretical generalization of experimental data. The research has resulted in developing experimental borehole hydraulic monitors and determining basic technical parameters of high-pressure water jets; determining regularities of hydraulic monitor disintegration of high-grade martite ores considering structural and mineralogical characteristics of the ores and hydrodisintegration modes; proving the fact that the process of high-grade martite ore disintegration by monitors is also the process of ore disintegration to the level of ore mineral grain release providing the higher quality disintegration product after subsequent dewatering than that of the initial one. The scientific novelty of the research consists in determining a criterion of hydrodisintegration of martites, conditions of forming a required fractional composition of monitor disintegration products through controlling stability of a pulse of the water jet action on the stope face. The practical relevance of the monitor breaking process in conditions of mining units at deep levels of Kryvbas underground mines consists in providing advanced stoping of rich martite ores through raises and obtaining a new kind of product - martite superconcentrate.
\end{abstract}

\section{Introduction}

Nearly a quarter of reserves of high-grade martite ores with iron content of $65-69 \%$ occurs relatively compactly and in accordance with natural mineralogical zonation at deep levels of Kryvbas mines within ore bodies structured by ore types [1-4]. Chemical and mineral characteristics of such ores allow treating them as a prospective raw material base for iron ore superconcentrate production with stable chemical and technological parameters and wide suitability/consumer properties $[5,6]$. Structural and morphological features of

\footnotetext{
*Corresponding author: mstupnik2012@gmail.com
} 
high-grade martite massifs, their instability and low strength do not allow traditional selective mining without significant qualitative and quantitative losses when applying common sublevel caving options based on blasting and areal ore drawing.

Advance stoping of high-grade instable ores applying the borehole hydraulic technology is one of the resource saving directions of mining structured ore bodies. The technology provides for disintegration of rock massifs by monitors through boreholes [7]. Implementation of the new principle in underground iron ore disintegration enables: provision of sufficient stability of formed stopes without disturbing continuity of the massif of leaner and stronger ores with their further mining as compensatory areas; enhancement of the applied mining system structures; increase of mining operations concentration, safety and efficiency. The new method of breaking in rich iron ore deposits of Kryvbas will enable production of a new iron ore product and increase competitiveness of Kryvbas underground mines on metallurgical markets.

Water jet energy is known to be used to disintegrate millions of tons of various rocks, ores and coals: when washing out weak overburden rocks by surface direct-flow monitors in open-pit mining; when mining coals by underground direct-flow monitors in collieries; at remote disintegration of construction materials, chemical raw materials, non-ferrous and rare earth ores by borehole monitors from the daylight surface or in underground mines.

Analysis of the theory and practice of hydraulic monitor disintegration of rocks show [8 11] that organization principles and methods of calculating process parameters are mainly based on the general concept of the disintegration mechanism and empirical regularities obtained in particular mining and geological conditions of coal deposits. Technical and technological parameters of rock disintegration by monitors high-pressure water jets and its efficiency are determined depending on mining and technological properties of rocks, hydrodynamic characteristics and methods of water jet impacts on rocks.

The process of disintegrating rich iron ores by monitor waters jets through boreholes still remains understudied. This deters experimental and industrial testing and practical application of the method under challenging engineering-geological conditions of Kryvbas iron ore underground mines.

The work is aimed at determining parameters of borehole stoping by hydraulic monitors leading to rational use of reserves structured according to ore types in ore bodies by means of advance stoping with selective disintegration of high-grade martite ores.

Investigation of the process of disintegrating martite ores by high-pressure water jets involved solution of the interrelated problems:

- development of experimental underground borehole monitors for breaking weak iron ores and determination of hydrodynamic and geometric characteristics of free high-pressure water jets;

- experimental investigation of the mechanism characteristics and determination of basic parameters and regularities of disintegrating high-grade martite ores by monitor water jets through boreholes;

- determination of chemical and mineralogical characteristics and technological properties of monitor disintegrated products.

According to [2, 4], high-grade martite ores at deep levels of Krivbass underground mines are structurally fine-grained, highly porous, mainly two component systems containing $90-95 \%$ of martite and $5-10 \%$ of quartz in volume. Their characteristics are as follows: iron content $-66.6-68.8 \%$ (average $67.9 \%$ ); silica content $-1.0-2.0 \%$ (average $1.45 \%$ ); density $-3.50-3.99$ (average 3.68 ) $10^{3} \mathrm{~kg} / \mathrm{m}^{3}$; porosity $-20-38 \%$ (average 30\%); uniaxial compressive resistance - $0.8-10 \mathrm{MPa}$ (average 4.6 MPa).

The stable relationship between uniaxial compressive resistance and porosity is described as follows: 


$$
\left[\sigma_{c r}\right]=\left[\sigma_{q}\right] \cdot(1-\eta)^{2} \cdot e^{-12 \eta}
$$

where $\left[\sigma_{q}\right]$ is uniaxial compressive resistance of oxidized quartzite (jaspilites or hornfels) similar to porous martite ores by genesis, composition and structure, MPa; $\eta$ - general porosity of martite ores, fr.unit.

Rotating water jets form a worked out out areas in martite massifs through cutting down the raise until a quasi-cylindrical room of the designed sizes is formed (Fig. 1).
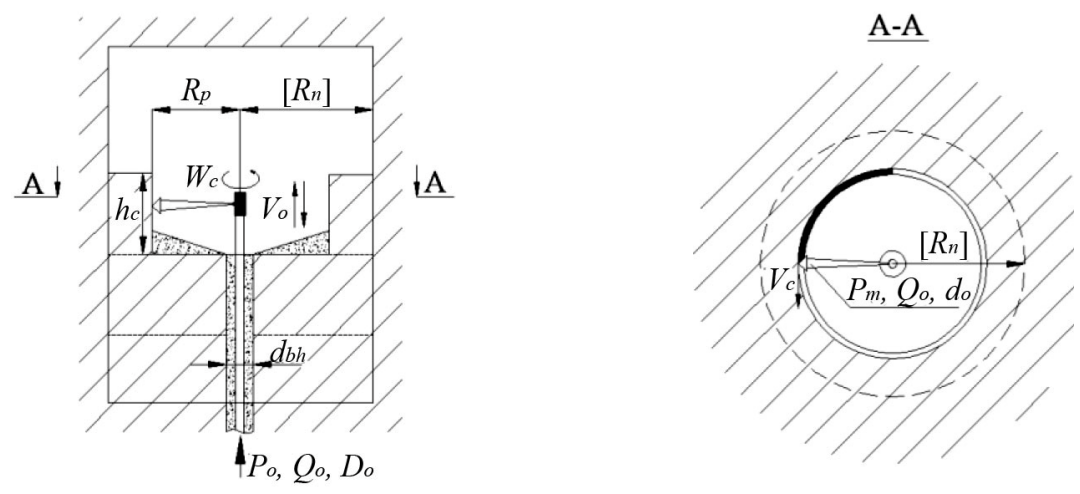

Fig. 1. Calculated diagram of monitor disintegration of martite ores by rotating jets: $P_{o}, Q_{o}, D_{o}$ are pressure, consumption and diameter of the technological water flow respectively; $d_{b h}$ is a borehole diameter; $R_{c},\left[R_{m}\right]$ are current and maximum radii of disintegration; $h_{c}$ is height of the disintegrated ore layer; $W_{v}, V_{v}$ are angular and linear velocity of a jet travel in a face respectively; $V_{o}$ is a velocity of jet reciprocal movements; $P_{m}$ is a axial dynamic pressure of a jet; $d_{o}$ is a nozzle diameter.

Breaking of iron ores by monitors is a nonstationary process. Its parameters depend on hydrodynamic characteristics of a water jet varying with the distance to ore exposures, velocity of jet travels in a face and structural and mineralogical features of the ore massif.

\section{Methods}

The process of monitor disintegration of high-grade loose iron ores has undergone experimental investigations in mining geological and technical conditions of mining units of $950-1240$ m levels at "Rodina" and "Yuvileina" iron ore underground mines, Kryvyi Rih iron ore basin.

General methods of investigation involved: choosing representative areas of high-grade martite ores in structured iron ore bodies; developing experimental underground plants; choosing methods of controlling and measuring technical and technological parameters of breaking; conducting experimental and methodological work on disintegrating ores by high-pressure water jets through boreholes from underground workings; sampling and determining fractional and chemical compositions of hydraulic breaking products; determining characteristics of their concentration; analyzing and generalizing experimental results and determining technical and technological parameters of martite ores hydraulic breaking.

\section{Results and discussion}

To conduct field investigations a prototype and experimental plants were designed and built. The parameters of the prototype are as follows: water pressure in the nozzle $P_{o}$ varies from 
1 to $8 \mathrm{MPa}$ at the water consumption $Q_{o}=2.9 \mathrm{~m}^{3} / \mathrm{h}$ through the initial jet diameters $\mathrm{d}_{\mathrm{o}}$ varying from 3.0 to $4.5 \mathrm{~mm}$. Parameters of the experimental monitor (Fig. 2) are as follows: water pressure in the nozzle $P_{o}$ varies from 0.5 to $2.5 \mathrm{MPa}$ at the water consumption $Q_{o}=38 \mathrm{~m}^{3} / \mathrm{h}$ the initial jet diameters $d_{o}$ varying from 10 to $15 \mathrm{~mm}$.

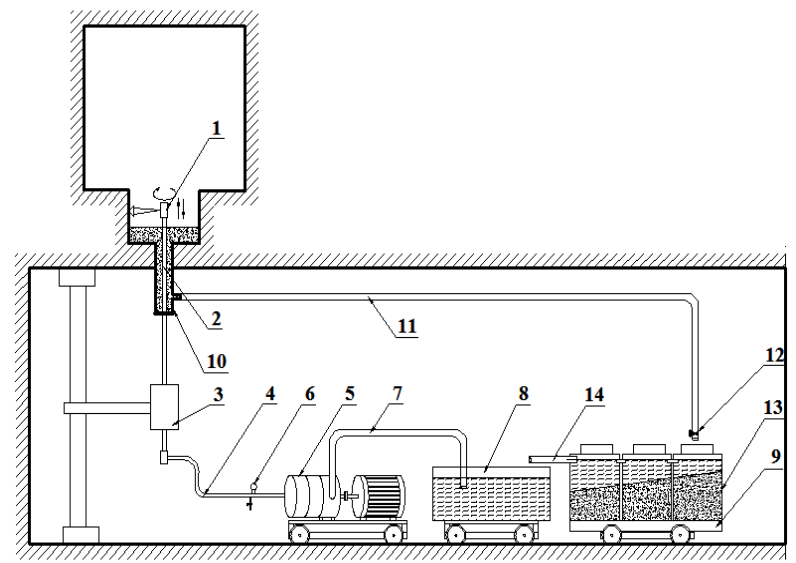

Fig. 2. Diagram of the experimental monitor plant: 1 - monitor head, 2 - monitor barrel, 3 - monitor unit, 4 - high-pressure hose, 5 - pump, 6 - manometer, 7 - water pipe, 8 - water tank, 9 - container platform, 10 - production hole preventer, 11 - pulp line, 12 - discharge device, 13 - hydrodisintegrated products, 14 - water overflow.

Monitors were tested in various modes of initial parameters. The experimental data demonstrated that monitor efficiency is characterized by the integral parameter of jet compactness - its initial part length $\mathrm{L}_{\mathrm{i}}$ where the axial dynamic pressure $P_{m}$ equals the pressure of the fluid going out of the jet forming nozzle $P_{o}$. For borehole monitors the value $L_{i}$ is determined from the expression:

$$
L_{i}=(95-50 R e) d_{o}
$$

where $d_{o}$ is the jet forming nozzle outlet diameter, m; $R e=V_{o} d_{o} / v$ is the Reynolds number; $V_{o}=42 \sqrt{P_{O}}$ is the initial velocity of the outgoing jet, $\mathrm{m} / \mathrm{s} ; \mathrm{v}$ is kinematic viscosity of the fluid (for water at $t=20^{\circ} \mathrm{C}, v=1.01 \cdot 10^{-6}$ ).

Changes of the jet parameter $P_{m}$ (Fig. 3) beyond $L_{i}$ are normally described by the following dependency:

$$
P_{m}=P_{o}\left(L_{i} / L_{e}\right)
$$

where $L_{e}$ is the length of the effective part of the jet, $\mathrm{m}$.

For experimental borehole monitors, the length of the effective part of the jet $L_{e}$ should be assumed equal to $(8-10) L_{i}$. Here, the average working diameter $D_{w}$ of the disintegrating part of the jet throughout its effective part $L_{e}$ will equal $(6-8) d_{o}$.

The primary objective of experiments in underground conditions is to determine principal features of the monitor disintegration mechanism and elicit dominant influencing factors through visual and instrumental observations.

It is determined that the axial dynamic pressure in the monitor jet which makes:

$$
\left[P_{m}\right]=0.25\left[\sigma_{c r}\right]
$$

or considering (1) 


$$
\left[P_{m}\right]=0.25\left[\sigma_{q}\right] \cdot(1-\eta)^{2} \cdot e^{-12 \eta},
$$

can serve as a criterion of disintegration of highly porous martite ores with mass content of iron of over $65 \%$.

Main results of the experiments with the prototype are given in Tables 1 and 2.

Table 1. Sieve composition of high-grade martite ore fragmented by various processes.

\begin{tabular}{|c|c|c|c|c|c|c|c|c|c|}
\hline \multirow{2}{*}{ Size, mm } & \multicolumn{2}{|c|}{$\begin{array}{c}\text { Blasting destruction of } \\
\text { ore by hole charges }\end{array}$} & \multicolumn{3}{|c|}{ Ore milling } & \multicolumn{3}{|c|}{$\begin{array}{c}\text { Monitor disintegration of } \\
\text { ore }\end{array}$} \\
\cline { 2 - 10 } & $\begin{array}{c}\text { yield, } \\
\%\end{array}$ & $\begin{array}{c}F e \text { mass } \\
\text { fraction, } \\
\%\end{array}$ & $\begin{array}{c}\text { release, } \\
\%\end{array}$ & $\begin{array}{c}\text { yield, } \\
\%\end{array}$ & $\begin{array}{c}F e \text { mass } \\
\text { fraction, } \\
\%\end{array}$ & $\begin{array}{c}\text { release, } \\
\%\end{array}$ & $\begin{array}{c}\text { yield, } \\
\%\end{array}$ & $\begin{array}{c}F e \text { mass } \\
\text { fraction, } \\
\%\end{array}$ & $\begin{array}{c}\text { release, } \\
\%\end{array}$ \\
\hline+2.0 & 45 & 67.4 & 0.0 & 3.0 & 63.8 & 0.0 & 2.8 & 62.7 & 0.0 \\
\hline$-2.0+1.0$ & 10.2 & 68.1 & 0.0 & 9.6 & 65.5 & 0.0 & 11.3 & 68.3 & 2.0 \\
\hline$-1.0+0.5$ & 10.9 & 68.3 & 0.0 & 13.7 & 68.0 & 3.0 & 16.8 & 68.8 & 5.0 \\
\hline$-0.5+0.25$ & 7.2 & 68.1 & 0.0 & 13.0 & 66.7 & 8.0 & 14.8 & 67.8 & 10.0 \\
\hline$-0.25+0.1$ & 9.0 & 68.0 & 0.0 & 3.3 & 67.3 & 50.0 & 26.5 & 68.9 & 96.0 \\
\hline$-0.1+0.074$ & 4.8 & 66.1 & 4.0 & 14.8 & 68.6 & 60.0 & 12.7 & 67.2 & 100.0 \\
\hline$-0.074+0.044$ & 2.8 & 66.1 & 10.0 & 6.3 & 67.7 & 85.0 & 7.0 & 67.9 & 100.0 \\
\hline-0.044 & 1.5 & 66.0 & 8.0 & 36.3 & 67.1 & 90.0 & 8.1 & 68.7 & 100.0 \\
\hline Total & 100 & 67.7 & 6.0 & 100 & 67.2 & 20.5 & 100 & 68.3 & 45.0 \\
\hline
\end{tabular}

As is seen from Table 1, milling produces by $25 \%$ fewer free martite grains than disintegration by monitors. The $-0.044 \mathrm{~mm}$ size yield is larger by $28 \%$. This can be explained by the fact that in milling ore minerals are overground due to the spongy nature of martites. Full ore particle release is achieved at grinding to the size of less than $0.25 \mathrm{~mm}$ which is comparable with martite grains.

Thus, borehole monitor disintegration is a combined process of ore preparation that includes milling and sizing of disintegrated products.

Table 2. Fractional composition of integrated ore samples.

\begin{tabular}{|l|c|c|c|c|}
\hline \multirow{2}{*}{ Size, $\mathrm{mm}$} & \multicolumn{4}{|c|}{ Initial water jet pressure, MPa } \\
\cline { 2 - 5 } & 1.5 & 2.5 & 3.5 & 4.0 \\
\cline { 2 - 5 } & \multicolumn{4}{|c|}{ Yield, \% } \\
\hline+1.0 & 18.2 & 28.9 & 30.0 & 30.3 \\
\hline$-1.0+0.5$ & 11.8 & 14.2 & 24.3 & 26.0 \\
\hline$-0.5+0.25$ & 25.2 & 19.7 & 13.7 & 16.2 \\
\hline$-0.25+0.1$ & 28.3 & 24.4 & 15.8 & 13.0 \\
\hline-0.1 & 22.5 & 12.8 & 8.2 & 4.5 \\
\hline Average particle size, $\mathrm{mm}$ & 0.514 & 0.663 & 0.739 & 0.763 \\
\hline
\end{tabular}

Table 2 demonstrates that at the same velocity of water jet movements along the face increase of the jet dynamic pressure results in the increased yield of the average size of hydrodisintegrated product particles due to the yield of smaller and released martite fractions.

One of the basic parameters that characterizes the process of porous martite ores disintegration by monitors is depth of technological disturbances of ore massifs at exposures. The experiments prove that at the jet dynamic pressure of $6-8 \mathrm{MPa}$, technogenic disturbance does not exceed $0.1-0.2 \mathrm{~m}$, i.e. is $20-30$ times less than at the ore massif disintegration by borehole explosive charges. 
The primary objective of the field experiments was to determine parameters of the disintegration process and their dependencies on initial hydrodynamic characteristics of a water jet and its mode of impacting the ore massif.

It is determined that in martite ores (porosity of $20-35 \%$ ) monitor jets with travel velocity of $0.5-3.0 \mathrm{~m} / \mathrm{s}$ and formed by a $10 \mathrm{~mm}$ nozzle under water pressure of 2.5 to 3.0 $\mathrm{MPa}$ provide the following parameters: pulp production -40 to $60 \mathrm{t} / \mathrm{h}$, solid fraction production -12 to $25 \mathrm{t} / \mathrm{h}$, specific water consumption -0.7 to $3.0 \mathrm{~m}^{3} / \mathrm{t}$; pulp density -1.3 to $1.5 \mathrm{t} / \mathrm{m}^{3}$, radii of the jet disintegration impact on the ore massif - from 2.0 to $3.0 \mathrm{~m}$.

The kinetic process of disintegration in the same ore massif is known to run in a number of ways depending on the type, character and value of the actual load. The results of monitor breaking demonstrate the following. The jet interacts with the disintegrated massif and in the subsurface part of the limited volume of the latter there occur and develop fields of secondary stresses. The fields are caused by normal and tangential components of the jet impact rate and spreading and by continuous change of the contact surface geometry. This conditions the disintegration process kinetics.

It is quite obvious that a high-pressure hydraulic impact on a certain exposure surface area/ exposed area in a limited ore volume results in development of all systems of pores and fractures, as well as new input microfractures in places of intergrain contact exposures - an interphase boundary or defects of intergrain surfaces. The fluid flow impacted by pressure heads for fractures and reaches their tops provoking fracture development. At first, as the velocity is rather great, the fluid reaches the fracture top in a short time provoking its growth. However, the fluid flow in the narrow fracture is characterized by appreciable fluid losses. Fluid pressure in longer fractures decreases quickly and becomes insufficient for their disruption but still acts as a lever or a wedge increasing concentration of tension stresses in the fracture top. This effect is of considerable significance for fracture elongation at the next action of the jet.

Thus, in a certain volume of rocks emerging hydrostresses cause ordered disintegration in the form of ore jointings, grain aggregates and mineral grains proper. Considering the above mentioned, it can be concluded that fractional analysis of jointings resulted from disintegration by monitors can serve as a source of information on character and features of the monitor disintegration process and for developing recommendations on its streamlining. Apparently, grains and aggregates will be formed in a thin, commensurate with sizes of grains and grain aggregates, layer near the surface of jet contact exposures as a result of disintegration by rupture - washout of intergrain contacts. As a result of ruptures, the lump part will be formed some distance inward from the exposure. It follows from the above mentioned that disintegration mechanism is a volume-differential one and depends on jet parameters and the ore massif state. At that, one part of water selectively disintegrates the ore until grains and their aggregates, another part disintegrates the ore massif to lump fractions and takes them to the pulp-preparation place, another part of water penetrates into technogenic fractures to the depth of up to $0.1-0.15 \mathrm{~m}$ and stays there as a hydraulic wedge till the next action cycle.

The given disintegration mechanism scheme demonstrates that monitor disintegration in highly porous martite ores by a travelling fluid jet will mainly occur by development and integration of fracture systems caused by tension stresses and wedging actions of the fluid. The breaking stress depth will be proportional to the fluid pressure and their lifetime will depend on the fluid action time. Tentatively, the disintegration mechanism is characterized by one of the strength parameters of the environment, e.g. compressive resistance $\left[\sigma_{c r}\right]$ that correlates with martite grain sizes and intergrain bond strength.

Thus, the technology of rock disintegration by monitors through boreholes satisfies the conditions of selective disintegration the physical significance of which consists in providing disintegration along boundaries of mineral grains and jointing fractures as a 
result of shear and tension stresses. Monitor disintegration can replace the whole technological line of disintegrating ore materials at the stage of preparation for concentration and result in energy savings and economic benefits.

Considering the obtained results of the maximum use of the effective part of a jet, the following condition should be fulfilled:

$$
\left[P_{o}\right]=2.5\left[\sigma_{c r}\right]
$$

The maximum efficient jet part:

$$
\left[L_{e}\right]=\frac{P_{o} \cdot L_{O}}{0.125\left[\sigma_{c r}\right]},
$$

for the type of mined ores is the basic structural parameter when choosing hydraulic mining locations.

The experiments show that, all things being equal, the disintegration degree (fractional composition of disintegrated products) crucially depends on the velocity $V_{v}$ of a jet travel velocity in the face, i.e. on the jet-massif contact time $t_{c}$.

The travelling jet-massif contact time is determined as follows:

$$
t_{c}=D_{p} / V_{v}
$$

For the jet travelling round the monitor in the borehole at the distance $L_{e}$ :

$$
V_{v}=2 \pi L_{e} n
$$

where $n$ is the angular velocity of a jet rotating round the axis of the borehole monitor barrel, rps.

The analysis show that the process of disintegrating the massif by a travelling water jet is characterized by the specific impulse of the power dynamic pressure of a jet on the ore massif equal to

$$
I_{m}=P_{m} \cdot t_{c}
$$

or

$$
I_{m}=\frac{K}{L_{e}^{2} n},
$$

where $K=2 P_{o} L_{i} d_{o}$ is a monitor dimension-type factor.

It is determined that for the required fractional composition of disintegrated products there exists a threshold value of the specific impulse of the axial dynamic pressure, $I_{m}$ which integrally reflects structural-textural and mineralogical features of ores, geomechanics of the ore massif, technology and parameters of the jet impact on the massif. The value $\left[I_{m}\right]$ for concrete engineering and geological conditions and the required degree of disintegration is determined experimentally.

As is seen from (11), the jet rotation velocity $n$ is a controlled parameter ensuring the required mode of ore massif disintegration by monitors at varying and controlled $L_{e}$.

Considering the fact that for every monitor dimension-type, parameters $P_{o}, L_{n}, d_{o}$ possess concrete values and that the required fractional composition is controlled by the constant value $\left[I_{m}\right]$, expression (11) is transformed into:

$$
L_{e}^{2} \cdot n=\frac{K}{\left[I_{m}\right]}=[W] \approx \text { const },
$$

where $[W]=2 P_{O} \cdot L_{H} \cdot d_{O} /\left[I_{m}\right]$ is the value constant for concrete conditions and integrally 
reflecting engineering and mineralogical features of the massif, the ore disintegration degree, monitor parameters and the disintegration technology.

Thus, for the given geological and technological characteristics of the ore massif the procedure of calculating basic parameters of disintegration by monitors include:

- choosing a monitor type and parameters and calculating basic structural and hydrodynamic characteristics of borehole monitor jets;

- calculating technological parameters of production holes and dead areas;

- choosing the required mode of disintegration by monitors to provide either breaking or disintegration or selective disintegration;

- calculating technical and economic parameters of ore massif disintegration for the required product type.

Iron ore concentrate obtained by gravity concentration of hydrodisintegrated products on concentrating tables (Table 3 ) was characterized by mass content of iron of up to $70 \%$ and that of silicon dioxide of up to $0.1 \%$. The characteristics satisfy requirements of iron powder, ferrite and battery paste production. Martite superconcentrate tested by the Ferroceram company satisfies all requirements for production of high class barium ferrite.

Table 3. Results of gravity concentration of high-grade martite ore at different ore preparation methods.

\begin{tabular}{|c|c|c|c|c|c|c|c|c|}
\hline \multirow{3}{*}{$\begin{array}{l}\text { Ore preparation } \\
\text { method }\end{array}$} & \multicolumn{4}{|c|}{ Concentrate } & \multicolumn{4}{|c|}{ Product } \\
\hline & \multirow{2}{*}{ yield, \% } & \multicolumn{2}{|c|}{ mass fraction, $\%$} & \multirow{2}{*}{$\begin{array}{c}\text { recovery } \\
\%\end{array}$} & \multirow{2}{*}{ yield, $\%$} & \multicolumn{2}{|c|}{ mass fraction, $\%$} & \multirow{2}{*}{$\begin{array}{c}\text { recovery } \\
\%\end{array}$} \\
\hline & & $\mathrm{Fe}$ & $\mathrm{SiO}_{2}$ & & & $\mathrm{Fe}$ & $\mathrm{SiO}_{2}$ & \\
\hline $\begin{array}{l}\text { disintegration by } \\
\text { monitors }\end{array}$ & 84.1 & 69.7 & 0.2 & 8 & 9 & 60.9 & - & 2 \\
\hline milling & 73.5 & 69.0 & 0.5 & 74.5 & 26.5 & 62.2 & - & 24.5 \\
\hline
\end{tabular}

\section{Conclusions}

The investigation resulted in:

- determining parameters, regularities and dependencies disintegration of high-quality martite ores by monitors through boreholes considering mining and geological characteristics of the ore massif, hydrodynamic parameters and methods of monitor jet application, and allowing rational control of ore granulometry, form and cavity sizes;

- proving the possibility of selective high-grade martite ore disintegration in Kryvbas underground mines which creates exceptionally favourable opportunities for organizing production of matrite superconcentrate with extremely high technological and economic parameters of a new level product for iron powder and high-class ferrite metallurgy.

Borehole disintegration of martite ores by monitors is promising and expedient when developing new technologies of selective mining of weak instable ores from structured iron ore deposits. It can also be applied for unmanned mining in vertical separated workings and creating rooms for various purposes.

This work was conducted within the projects "Determination of regularities of the stress-strain state of rocks disturbed by workings with the purpose of developing resource-saving ore mining technologies" (State registration No. 0115U003179).

\section{References}

1. Stupnik, N.I., Kalinichenko, V.A., Kolosov, V.A., Pismenniy, S.V., \& Fedko, M.B. (2014). Testing complex-structural magnetite quartzite deposits chamber system design theme. Metallurgical and mining industry, (2), 89-93. 
2. Stupnik, N., Kalinichenko, V., \& Pismennyi, S. (2013). Pillars sizing at magnetite quartzites room-work. Mining of Mineral Deposits, 11-15. http://dx.doi.org/10.1201/b16354-4.

3. Tarasyutin, V.M. (2015). Geotehnology features of high quality martite ore from deep mines of Kryvyi Rih basin. Naukovyi Visnyk Natsionalnoho Hirnychoho Universytetu, (1), 54-60.

4. Yevtekhov, V.D., Paranko, I.S., \& Yevtekhov, Ye.V. (2001). Heolohiia i korysni kopalyny Kryvorizkoho zalizorudnoho baseinu. Kryvyi Rih: Kryvorizkyi tekhnichnyi universytet.

5. Balashov, A.G., \& Anisimov, V.N. (2004). Bogataya ruda KMA v metallurgicheskom proizvodstve. Gornyy zhurnal, (1), 69-70.

6. Kravtsov, Ye.N., \& Kravtsov, N.K. (2004). Razrabotka tekhnologii polucheniya zhelezorudnogo kontsentrata iz rud podzemnoy dobychi s massovoy doley kremnezoma do $0.03 \%$. Razrabotka rudnykh mestorozhdeniy, 98-100.

7. Arens, V.Zh. Babichev, N.I., \& Bashkatov A.D. (2007). Skvazhinnaya gidrodobycha poleznykh iskopayemykh. Moskva: Izdatelstvo "Gornaya kniga".

8. Britan I.V. (2007). Ispytanie skvazhinnogo gidrodobychnogo oborudovaniya dlya otboyki rudy v zatoplennykh kamerakh. Gornyy informatsionno-analiticheskiy byulleten', (7), 286-291.

9. Malanchuk, Z.Ye., \& Boblyakh, S.N. (2007). Doslidzhennia protsesu rozmyvu zernystykh fosforytiv hidromonitornym strumenem. Visnyk Kryvorizkoho Tekhnichnoho Universytetu, (16), 33-38.

10. Petrichenko, V.P. Kolesnikov, V.I., \& Pinchuk, A.V. (2005). Fizicheskie sposoby i sredstva razuplotneniya i erliftirovaniya rykhlykh rud KMA. Gornyy informatsionno-analiticheskiy byulleten', (3), 283-287.

11. Stets, S.Ye. (2006). Eksperymentalne doslidzhennia protsesu hidrozmyvu tseolitsmektytovykh tufiv. Visnik Natsionalnoho Universytetu Vodnoho Hospodarstva, 4(36), 365-370. 